\title{
EXPERIMENTAL STUDIES IN THE TREATMENT OF TETANUS AND ON A CASE OF TETANUS TREATED WITH USNIC ACID*
}

\author{
MUTSUO HEKI, TOSHIO NISHIKAWA AND MIKI FUJII \\ The Medical Clinic, Faculty of Medicine, Kanazawa University
}

\section{INTRODUCTION}

For the treatment of tetanus, four ways should be considered; the first is the surgical treatment of wound, the second, the application of chemotherapeutics or antibiotics, the third, the injection of antitoxic serum and the fourth, the use of spasmolytics, especially of myanecin, introduced in recent time. All of the above ways should not be neglected, but one of the latest problems of interest in this field was as to whether penicillin is actually effective in clinical cases, through, naturally, other antibiotics, introduced later, may come in question, too.

Now, as for the effectiveness of penicillin, there are reports by Buxton and Kurman ${ }^{(1)}$, Weinstein and Wesselhoeft ${ }^{(2)}$, Altemeier ${ }^{(3)}$, Lewis ${ }^{(4)}$, Suzu$\mathrm{ki}^{(5)}$, Grove( ${ }^{(6)}$, Maruyama and Tsuji ${ }^{(7)}$, Diaz-Rivera ${ }^{(8)}, \mathrm{Usami}^{(9)}$, Kubo and others $^{(10)}$, etc., the most interesting of which, however, is the record of Diaz-Rivera, who had discussed penicillin treatment of tetanus cases. He estimated the mortality as $17.6 \%$ with 59 cases, treated with antitoxic serum combined with penicillin. The mortality of the cases, treated only with antitoxin serum hitherto, was ranging from 50 to $60 \%$ according to his experience, and therefore the treatment of tetanus must have certainly been improved by the introduction of penicillin after him, while the results by other investigators, obtained experimentally or clinically, were not always in accord with his steatment.

The present paper is dealing with the effectiveness of various chemical compounds and antibiotics, inclusive of penicillin; in experimental tetanus infection. Also an interesting case of tetanus, successfully cured with usnic acid, is presented as an addendum.

* Presented in part, at the 48th Annual Meeting of the Japanese Society of Internal Medicine, Tokyo, April 2, 1951. 


\section{EXPERIMENTAL}

A. The bacteriostatic and Bactericidal Effect of Agents on the Growth of Chlostridium tetani in vitro.

Meterials and Methods

The strain of Chlostridium tetani: Two strains, named the Continental Serum Strain and the U.S.A. Strain, were used in the experiment. Bacterial suspension: Cultures were grown in liver-liver bouillon ( $\mathrm{pH} \mathrm{7.4),}$ incubated for 72 hours at $37^{\circ} \mathrm{C}$ and kept for 5-7 days at room temperature. At the time of transplantation of bacilli, the tube was vigorously shaken and one platinum loop of bacillary suspension was used.

Examination of the bacteriostatic and bactericidal activities of the agents: In a set of tubes, each containing $2.0 \mathrm{cc}$ of liver bouillon ( $\mathrm{pH} \mathrm{7.4)}$ and two pieces of liver weighing from $0.5-0.7 \mathrm{~g}$ (the tubes were sterilized 3 times, every time for 30 minutes at $100^{\circ} \mathrm{C}$ ), the first tube received $2.0 \mathrm{cc}$ of $1: 500$ dilution of the agents, $2 \mathrm{cc}$ of the well mixed solution was transferred into the next tube, the same quantity from the second into the third and thus varying concentration of agents were obtained. A control tube contained only the nutrient fluid. Next, each tube was inoculated with the above bacillary suspension and incubated for 72 hours at $37^{\circ} \mathrm{C}$. The minimum inhibitory concentration of the agents on the growth of bacilli was determined from the tube showing no gas formation without turbidity observed in the fluid.

For the test of bactericidal activity of the agents, one drop of each culture was inoculated into a fresh liver-liver bouillon after 72 hours' incubation and the growth of bacilli was noted again after incubation for the same hours.

The water insoluble chemicals were disolved thereby in alcohol, pyridine or dioxan in 1:100 concentration preliminarily. To $1 \mathrm{cc}$ of the original solution of the agents, $4 \mathrm{cc}$ of liver bouillon was added and 1:500 diluted solution was made for further successive dilutions, mentioned above. Precautions were taken against the effect of solvents themselves for the identification of activities of water insoluble agents. Among antibiotics, aureomycin, terramycin and chloromycetin were dissolved in $1 / 100 \mathrm{~N} \mathrm{HCl}$ solution and usnic acid in water as its potassium salt.

Agents: The chemical compounds and antibiotics, the activities of which were tested, were as follows: 
Sulfamines, diphenylsulfones and allied substances:
1) Prontosil rubrum
10) Marfanil sulfathiazole
2) Sulfamine
11) Sulfamethylthiazole
3) Acetsulfamine
12) Sulfaguanidine
4) Marfanil
13) Pyrimison (4-aminobenzene, $2^{\prime}-$ aminopyrimidyl $\left(6^{\prime}\right)$ sulfon)
5) P-Oxybenzenesulfonamide
14) 2-2'-Diaminodiphenylsulfide
6) Sulfapyridine
15) 4-Nitro-4'-hydroxydiphenylsul- fide
7) Sulfadiazin
16) Diason
8) Sufamerazin
17) Promin
9) Sulfathiazol

Quinones and quinolines:

18) P-Benzoquinone

21) 8-Oxyquinoline

19) Hydroquinone

22) Chininum hydrohloricum

20) Toluquinone

Phenithiazines and phenoxazines:

23) Phenoxazine

29) Methyleneblue zincchloride

34) 3, 6-Dinitrophenoxazine

30) 2, 4-Dinitrophenothiazine

25) 3-Nitro-6-chlorophenothiazine

31) 3-Nitrophenothiazine

26) 3-Amino-6-chlorophenothia-

32) 3-Nitrophenoxazine zine

27) 3, 6-Diaminophenothiazine

33) 1, 3-Dinitrophenoxazine

28) Methylenblue

34) 1, 3, 6, 8-Tetranitrophenoxazine Acridins :

35) Trypaflavin

37) Rivanol (2-Ethoxy-6, 9-diaminoacridin-lactate)

36) Tuberflavin (3, 6-Diamino-10acridinium lodide)

Tetronic acids:

38) -Phenyltetronic acid

41) Anilid of -phenylteronic acid

39) -Phenyltetronic acid -carbonic acid ethylester

42) Dianilide of -phenylteronic acid

40) Anilide of -phenyltetronic acid- -carbonic acid -ethyl ester 
Substances obtained from lichen and allied compounds:
43) Ushic acid
47) p-Orcellic acid*
44) Roccelic acid*
48) Monomethylether-p-orcellic acid methylester*
45) Gyrophoric acid*
49) Isoevernic acid*
46) Erythrin*
50) Orcin dicarboxylic acid diethyl- ester*

Antibiotics obtained from Aspergilli, Penicillin or Actinomyces:

51) Citrinin

52) Penicillin

53) Aureomycin
54) Terramycin

55) Chloromycetin

56) Streptomycin

Other substances:

57) dl-Mandelic acid

60) Mapharsol

58) dl-Acetylmandelic acid

61) Guanofuracine

59) o-Aminophenol

\section{RESULTS}

Among 61 agents above described, the following substances showed high or relatively high bacteriostatic activities: marfanil $(1: 10,000)$, marfanil-sulfathiazol (1:4,000), 2-2'diaminodiphenylsulfide $1: 2,000)$, 8-oxyquinoline $(1: 8,000)$, 3-nitrophenoxazine $(1: 1,6000)$, 1-3-dinitrophenoxazine $(1: 8,000)$ 1-3-6-tetranitrophenoxazine $(1: 8,000)$, trypaflavin $(1: 4,000)$, trypaflavin $(1: 2,000)$, anilide of phenyltetrone carbonic acid $(1: 2,000)$, usnic acid $(1: 2,000)$ monomethylether-p-orcellic acid methylester $(1: 2,000)$, aureomycin $(1: 2,560,000)$, terramycin $(1: 1,280,000)$, penicillin $(1: 576,000)$, chloromycetin $(1: 64,000)$, citrinin $(1: 4,000)$, mapharsol $(1: 4,000)$ and guanofuracine $(1: 64,000)$.

Among the synthetic compounds, the bactericidal activities of marfanil, marfanil-sulfathiazole, promin, diason and guanofuracine were investigated and it was elucidated that only guanofuracine was the same in its bactericidal as well as in its bacteriostatic activity. And the biological substances, aureomycin, terramycin, penicillin, chloromycetin and usnic acid showed the same behaviour as guanofuracine, their bactericidal and bacteriostatic activities being equal.

* Agents marked were generously supplied by Dr. Sakurai formaly professor of the School of Pharmacy, Kanazawa. 
B. The Effect of Drugs in Experimental Tetanus Infection.

Methods

Animals: Mice weighing from 14 to $18 \mathrm{~g}$ were used in the experiment.

Strain of bacilli: The U.S.A. Strain of Chlostridium tetani.

Suspension of spores: The above strain was grown in liver bouillon for more than one month ( 3 months at most) and the culture was heated at $75-80^{\circ} \mathrm{C}$ in water bath for one hour to destroy the toxin as well as bacilli except spores.

Inoculation: Sterilized pieces of wood (about $3 \mathrm{~mm}$ long and $1 \mathrm{~mm}$ square) were dipped in the suspension of spores above mentioned, transferred in a sterilized glass dish and stored under low pressure in a desiccator over sulfuric acid, which was kept in dark place. For the inoculation, hairs in the gluteal region of mice were cripped and disinfected with alcohol, where a small incision was made and a piece of wood prepared as above, was inserted through it. The incision was sealed with collodion.

Treatment: Every time, prior to the experiment of treatment, 3 mice were inoculated with spores and the virulence was checked to see that it was sufficiently high enough to kill the animals in 5-6 days at the latest. When the virulence was proven to be satisfactorily high, animals were infected anew with bacilli in the same way and the injection of drug was begun 1 hour after inoculation (unless specifically mentioned otherwise). The drug solution to be given at one time was restricted to $0.3 \mathrm{cc}(0.6 \mathrm{cc}$ consequently, when two drugs were injected simultaneously). It was injected subcutaneously around the inoculated region and was repeated daily for 3 or 6 days, then observation was made for one month to see whether the animals fell sick or died. Besides, certain number of animals were infected in the same way to serve as controls, which should die within 56 days. After the termination of experiment of the servived animals, the inserted pieces of wood were taken out and were placed into liver bouillon for the detection of Chlostridium tetani.

Agents: As chemical compounds, sulfadiazin, sulfamerazin, sulfathiazole, marfanil-sulfathiazole, marfanil, promin, diason and guanofuracine were selected for the experiment. Water insoluble substances as themselves were dissolved as their sodium salts. And as antibiotics, penicillin $\mathrm{G}$ (potassium salt), aureomycin- $\mathrm{HCl}$, terramycin- $\mathrm{HCl}$, chloromycetin, streptomycin- $\mathrm{HCl}$ and usnic acid (potassium salt) were used in the experiment. 
Aureomycin, terramycin and chloromycetin were dissolved in $1 / 100 \mathrm{~N} \mathrm{HCl}$ solution. Terramycin and chloromycetin were found entirely insoluble, but any organic solvents were avoided to prevent errors in the experiment.

\section{RESULTS}

1) Effect of penicillin.

First, the effect of penicillin was investigated. The results were very indefinite in repeated experiments. The results were not related to the range of amount of the drug adopted in our experiment. In the case of administration of 120 units daily per animal subcutaneously for 6 days, the survivals were $1 / 3$ (one out of 3 animals) or $0 / 4$, in the case of administration of 60 units, $2 / 4,1 / 4$ or $0 / 4$ and in the case of administration of 30 units $2 / 4,1 / 3$ or $1 / 4$. Even smaller amount seemed more effective than larger amount of the agent.

2) Effect of sulfamines, diphenylsulfones and guanofuracine.

Sulfadiazin, sulfamerazin, sulfathiazole, marfanil-sulfathiazole, marfanil, promin and diason were injected in the amount of $3 \mathrm{mg}$ per day for 6 days, but they demonstrated little effect against the infection. A slight effect was observed only in marfanil, with which the survivals were $0 / 4$, $2 / 4,1 / 4$ each in three experiments. In comparison with these agents, guanofuracine was more effective. In the case of administration of 0.6 mg daily per animal for 6 days, the survivals were $3 / 5$ and in the case of administration of $0.3 \mathrm{mg}$ daily for 6 days, the survivals were also $3 / 5$.

3) Effect of antibiotics other than penicillin.

The results, obtained with aureomycin, terramycin, chloromycetin and usnic acid were summarized in Table 1 .

Table 1.

The Results of Treatment of Tetanus with Antibiotics.

\begin{tabular}{|l|c|c|c|c|c|}
\hline \multicolumn{1}{|c|}{ Drugs } & $\begin{array}{c}\text { Method of } \\
\text { administration }\end{array}$ & Total & $\begin{array}{c}\text { Number } \\
\text { amount }\end{array}$ & $\begin{array}{c}\text { Number of ani- } \\
\text { of } \\
\text { animals } \\
\text { mals, became } \\
\text { once ill but was } \\
\text { restored spont- } \\
\text { aneously }\end{array}$ & $\begin{array}{c}\text { Survi- } \\
\text { vals }\end{array}$ \\
Aureomycin & $0.6 \mathrm{mg}$ for 6 & $3.6 \mathrm{mg}$ & 5 & 0 & $5 / 5$ \\
Terramycin & days & & 5 & 0 & $5 / 5$ \\
Usnic acid & & 3 & 0 & $3 / 3$ \\
Chloromycetin & & 5 & 0 & $3 / 5$ \\
Streptomycin & & 5 & 0 & $3 / 5$ \\
\hline
\end{tabular}




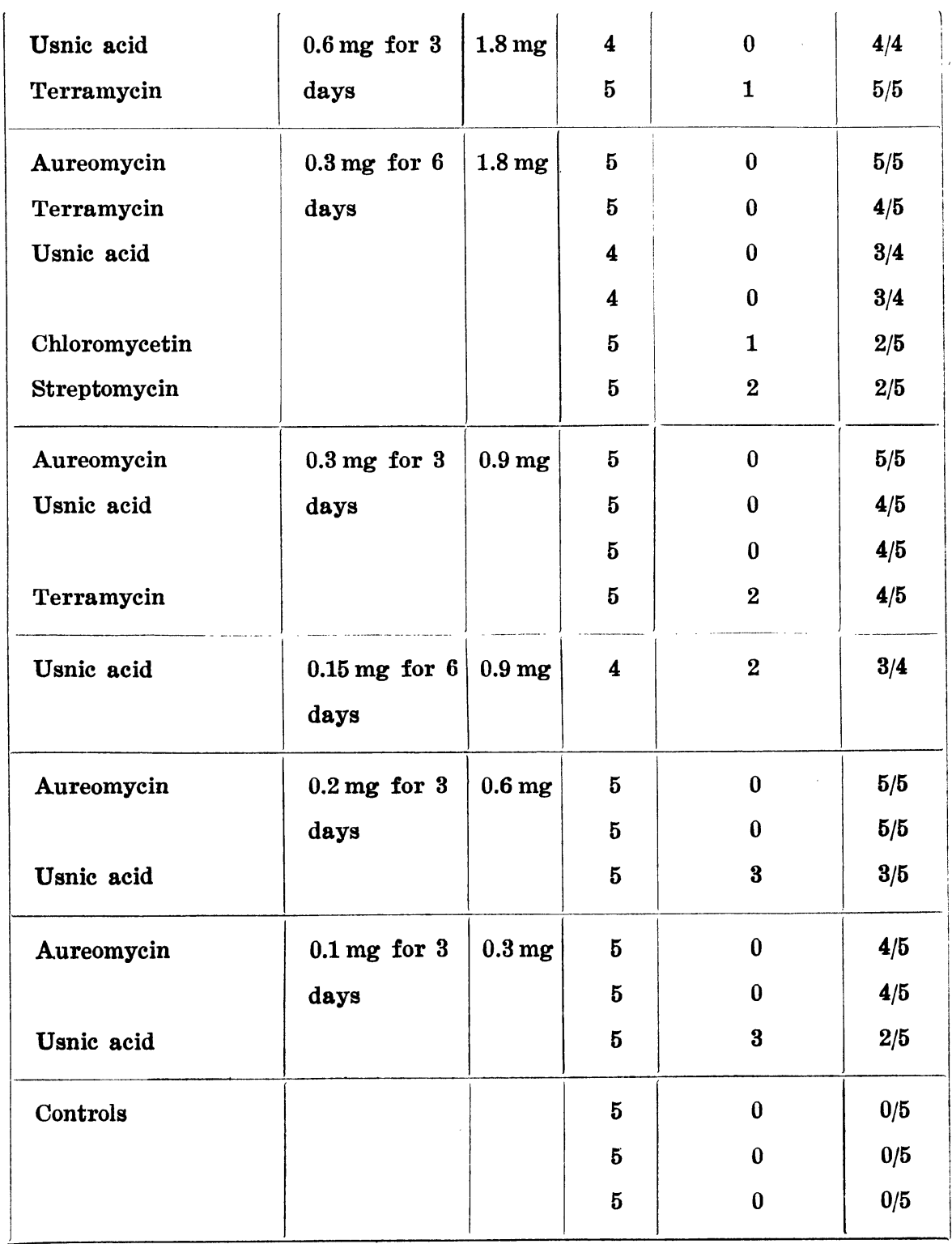

Now it is obvious that aureomycin is the most effective, followed by terramycin and usnic acid. With an adequate amount of the latter drugs, 100 per cent effectiveness was obtained, while the effectiveness was much lower with chloromycetin or streptomycin.

4) Effect of usnic acid in combination with penicillin.

The fact was now established from the above results that aureo- 
mycin is the most admirable agent as chemotherapeutic against tetanus infection, but it is also an undeniable truth that 100\% survivals of animals can be obtained with terramycin or with usnic acid. Specifically, the efficacy of usnic acid attracted our interest considerably, because the drug is available in abundance in our country from Usnea longissima and its extraction process is quite simple. In fact, usnic acid is somewhat more toxic than aureomycin or terramycin, but we have expected that this disadvantage might be conquored by some procedure, for example, by the combination with some of the other drugs. In the following results, the facts are presented that considerablly reduced units of penicillin is able to spare the amount of usnic acid to accomplish a perfect effectiveness in the treatment with the latter agent. In practice against tetanus infection, a small amount of usnic acid may be sufficient to suppress the disease, as it is used in the region of the wound. It might be needless to be bothered by the side effect of the drug, however the combination of those drugs may certainly be more advantageous than the single use of the drugs from the view point of the nature of such wound infection.

Table 2.

The Results of Treatment of Tetanus with Usnic Acid in

Combination with Penicillin.

\begin{tabular}{|c|c|c|c|c|}
\hline Drugs & $\begin{array}{c}\text { Method of } \\
\text { administration }\end{array}$ & $\begin{array}{c}\text { Number } \\
\text { of } \\
\text { animals }\end{array}$ & $\begin{array}{c}\text { Number of ani- } \\
\text { mals, became } \\
\text { once ill but were } \\
\text { restored spont- } \\
\text { aneously }\end{array}$ & $\begin{array}{c}\text { Survi- } \\
\text { vals }\end{array}$ \\
\hline \multirow[t]{2}{*}{ Usnic acid } & $0.3 \mathrm{mg}$ for 6 days & 4 & 1 & $3 / 4$ \\
\hline & & 4 & 1 & $3 / 4$ \\
\hline \multirow[t]{2}{*}{ Penicillin } & 30 units for 6 days & 3 & 1 & $1 / 3$ \\
\hline & & 4 & 1 & $2 / 4$ \\
\hline Usnic acid & $0.3 \mathrm{mg}$ & 3 & 0 & $3 / 3$ \\
\hline \multirow[t]{2}{*}{ Penicillin } & 30 units & 4 & 0 & $4 / 4$ \\
\hline & & 4 & 0 & $4 / 4$ \\
\hline \multirow[t]{3}{*}{ Controls } & & 4 & 0 & $0 / 4$ \\
\hline & & 4 & 0 & $0 / 4$ \\
\hline & & 4 & 0 & $0 / 4$ \\
\hline
\end{tabular}




\begin{tabular}{|c|c|c|c|c|}
\hline Usnic acid & $0.15 \mathrm{mg}$ & 4 & 1 & $3 / 4$ \\
\hline $\begin{array}{l}\text { Usnic acid } \\
\text { Penicillin }\end{array}$ & $\begin{array}{l}0.15 \mathrm{mg} \\
30 \text { units }\end{array}$ for 6 days & 4 & 0 & $4 / 4$ \\
\hline Controls & & 4 & 0 & $0 / 4$ \\
\hline Usnic acid & $0.20 \mathrm{mg}$ & 4 & 1 & $3 / 4$ \\
\hline $\begin{array}{l}\text { Usnic acid } \\
\text { Penicillin }\end{array}$ & $\begin{array}{l}0.20 \mathrm{mg} \\
30 \text { units }\end{array}$ & 4 & 0 & $4 / 4$ \\
\hline Controls & & 4 & 0 & $0 / 4$ \\
\hline
\end{tabular}

\section{ADDENDUM}

A Case of Tetanus Cured Sucessfully with Usnic Acid.

A mild case of tetanus might be cured with penicillin and anti-tetanus serum, and it will not particularly need any other new method of treatment. It is not always easy, therefore, to find a proper case to prove the superior effectiveness of a new drug. Although a treatment of tetanus with usnic acid in combination with penicillin was recommended as one of the admirable methods in the above description, it is, moreover, difficult to determine the effectiveness of each of the two drugs, when both drugs were administered simultaneously, because in some cases penicillin alone might be sufficiently effective to accomplish the same result. Once, however, usnic acid alone was proven to be effective to prevent the development of the disease, no doubt the fact will be convinced that the combined effectiveness of the acid and penicillin certainly may be higher.

By chance, we were able to attend a case of tetanus recently, in which subcutaneous and subdural injections of anti-tetanus serum, subcutaneous injection and local application of penicillin in the wound, and subcutaneous injection and oral administration of myanecin had not brought any notable effect to relieve the spasmodic condition of the patient, whereas intramuscular injection and local application of usnic acid sodium salt solution invited a prompt recovery of the patient from disease. Clinical report of the case is given in the following.

A 24 years old female was admitted on October 26, 1951 with a history of spasm of masseter since October 20 of the same year. 
On October 16, she had been working in the field, when she had her big toe of right foot cut by a hoe. She had a little bleeding from the wound, which was left as it was without any treatment. She felt the difficulty to open her mouth since October 20, which increased day by day.

Present status: Moderately nourished. Her face seemed a little poor in expression. Temperature, $37.1^{\circ} \mathrm{C}$ with a pulse rate of 90 per minute. Regular pulse with good tension. The respiration rate was 18 per minute. No swelling of lympnode was observed.

Pupillary light reflex normal. The movement of bulbi was not disturbed. The palpebral fissures were a little narrow, due to ptosis of upper eye lids. She could not open her mouth more than 1 finger width. There were no symptoms referrable to in the chest. The lower abdomen was stretched a little but with no pressure pain.

On the tip of big toe of right foot, a cut of about $1 \mathrm{~cm}$ in length was found the wound was closed containg blackish dirty mass in it. No abnormal tendon reflex and the disturbance of sensibility were observed.

The course and treatment: Clinical symptoms were about the same as in the day before on admission, but she could scarecely open her mouth (a half finger width) and took only fluid. Risus sardonicus was manifestly observed. Leukocyte count was 12,000 per cu. $\mathrm{mm}$. The nail of big toe was stripped off and the wound was incised. Penicillin guase was applied in the wound. Twelve thousand units each of anti-tetanus serum were injected twice and 200,000 units each of penicillin G 4 times subcutaneosly on that day.

October 27. In the provious night and in the early moring, she was attacked by cramp and had opisthotonos. Risus sardonicus was manifestly observed as ever. She took only fluid and the speech was scarecely audible. Eighteen thousand units of serum were subcutaneouly and 6,000 units subdurally injected. The similar amount of penicillin as the day before was administered 4 times a day. Myanecin was given orally (3 $\mathrm{g}$ in 3 does) and subcutaneously ( $0.2 \mathrm{~g} 4$ times) at the same time. After the subdural injection of serum, the lower abdomen was stretched severely, she complained of headache, vomitted and lost appetite entirely. The pressure of cerebrospinal fluid was $200 \mathrm{~mm}$ high at lying position and became $120 \mathrm{~mm}$ after removal of $15 \mathrm{cc}$. It was watery clear and had no sediments. Pandy's reaction was weakly positive.

October 28, She had attacks of cramp with opisthotonos twice in the 
midnight and in the early morning. She took no food because of loss of appetite. The injection of myanecin was given as in the day before, but the injection of penicillin was discontinued.

October 29. She was attacked by severe cramp four times from the midnight. The rigidity of neck was manifest and slight stimulus was apt to invite cramp. In the afternoon, $20 \mathrm{mg}$ of usnic acid potassium salt was injected intramuscularly for the first time, simultaneously with the administration of myanesin as in the day before.

October 30. The patient had mild attacks of cramp twice in the midnight and in the early morning. Usnic acid was injected in the amount of $20 \mathrm{mg}$ each twice a day.

October 31. The patient was able to open the mouth about 1 finger width. She was attacked by cramp once in the night. Myancein was given only per os and $20 \mathrm{mg}$ of usnic acid each injected twice.

November 1. No more cramp from this day. The patient took gruel and felt well all day. The treatment was given just in the same way as in the day before.

November 4. The patient was able to open her mouth about 2 finger widths and showed normal appetite. She could turn on the bed. She received the injection of usnic acid in the amount of $20 \mathrm{mg}$ once a day from this day.

November 6 . The patient could bend her neck freely.

November 8. The patient took meal sitting on her bed.

November 10. The injection of usnic acid was discontinued.

\section{SUMMARY}

In experimental tetanus infection of mice, aureomycin, usnic acid and terramycin were chosen as the most recommendable remedies among 61 agents tested. The combined effectiveness of usnic acid and penicillin was also admirable.

A case of tetanus, in which anti-tetanus serum, penicillin and myanecin could not help much, has been brought to promt recovery from the disease with usnic acid.

This case was admitted to the Kanazawa Hospital of the Department of Railways, examined and treated by Dr. N. Kibe and Dr. A. Koido under the direction of Dr. Heki. 


\section{REFERFNCES}

1) Buxton, R. and Kurman, R. L.: Tetanus; A Report of Two Cases Treated with Penicillin. J. A. M. A., 127, 26 (Jan. 6), 1945.

2) Weinstein, L. and Wesselhoeft, C.: Penicillin in Treatment of Tetanus: Report of Two Cases. New England J. Med., 233, 681-684, 1946.

3) Altemeyear, W. A. : Penicillin in Tetanus. J. A. M. A., 130, 67-72, 1946.

4) Lewis, L.: Penicillin in Treatment of Tetanus. Med. Time, July 5, 1947.

5) Suzuki, J.: Penicillin in Treatment of Surgical Diseases. Nippon Rinsho, 5, 264-273, 1947 (in Japanese).

6) Grove, J. L.: Tetanus treated with Penicillin. M. J. Australia, 1, 226-227, 1947.

7) Maruyama, I. and Tsuji, T.: A Case of Tetanus treated successfully with Penicillin. Diagnosis and Therapy, 36, 410-411, 1948 (in Japanese).

8) Diaz-Rivera, Deliz and Berio Suanrez: Penicillin in Tetanus. J. A. M. A., 138, 191-194, 1948.

9) Usami, S.: A Severe Case of Tetanus treated with Penicillin. Chirurugy, 10, 30-35, 1948 (in Japanese).

10) Kubo, I. and Others: Two Cases of Tetanus treated with Penicillin. J. Antibiotics, 3, 935-936, 1950 (in Japanese). 